\title{
The clinical and economic burden of chronic obstructive pulmonary disease in the USA
}

This article was published in the following Dove Press journal:

ClinicoEconomics and Outcomes Research

14 June 2013

Number of times this article has been viewed

\author{
Anthony J Guarascio' \\ Shauntá M Ray' \\ Christopher K Finch ${ }^{2,3}$ \\ Timothy H Self ${ }^{2}$ \\ 'University of Tennessee College \\ of Pharmacy, Knoxville, ${ }^{2}$ University \\ of Tennessee College of Pharmacy, \\ Memphis, TN, USA; ${ }^{3}$ Methodist \\ University Hospital, Memphis, TN, USA
}

Correspondence: Shauntá M Ray College of Pharmacy, Graduate School of Medicine, University of Tennessee Health Science Center, 1924 Alcoa Highway, Box II2, Knoxville,

TN 37920, USA

Tel +l 8659742324

Fax +I 8659742022

Emailsmray@uthsc.edu
Abstract: Chronic obstructive pulmonary disease (COPD) is the third most common cause of death in the USA. In 2010, the cost of COPD in the USA was projected to be approximately US\$50 billion, which includes $\$ 20$ billion in indirect costs and \$30 billion in direct health care expenditures. These costs can be expected to continue to rise with this progressive disease. Costs increase with increasing severity of disease, and hospital stays account for the majority of these costs. Patients are diagnosed with COPD following a multifactorial assessment that includes spirometry, clinical presentation, symptomatology, and risk factors. Smoking cessation interventions are the most influential factor in COPD management. The primary goal of chronic COPD management is stabilization of chronic disease and prevention of acute exacerbations. Bronchodilators are the mainstay of COPD therapy. Patients with few symptoms and low exacerbation risk should be treated with a short-acting bronchodilator as needed for breathlessness. Progression of symptoms, as well as possible decline in forced expiratory volume in the first second of expiration $\left(\mathrm{FEV}_{1}\right)$, warrant the use of long-acting bronchodilators. For patients with frequent exacerbations with or without consistent symptoms, inhaled corticosteroids should be considered in addition to a long-acting beta ${ }_{2}$-agonist (LABA) or long-acting muscarinic antagonist (LAMA) and may even consist of "triple therapy" with all three agents with more severe disease. Phosphodiesterase-4 inhibitors may be an option in patients with frequent exacerbations and symptoms of chronic bronchitis. In addition to a variety of novel ultra-LABAs, LAMAs and combination bronchodilator and inhaled corticosteroid (ICS) therapies, other bronchodilators with a variety of mechanisms are also being considered, to expand therapeutic options for the treatment of COPD. With more than 50 new medications in the pipeline for the treatment of COPD, optimal management will continue to evolve and grow more complex as benefits of therapy are balanced with the limitations and needs of each patient.

Keywords: chronic obstructive pulmonary disease, COPD, clinical burden, economic burden

\section{Introduction}

Chronic obstructive pulmonary disease (COPD) is a term that encompasses both chronic bronchitis and emphysema. These two diseases are characterized by obstruction to airflow that interferes with normal breathing. Since both of these diseases often coexist, many health care professionals prefer the term COPD. ${ }^{1}$ Although some patients may have components of both COPD and another obstructive airway disease, asthma, this review concerns only COPD. Because of the significant worldwide burden of disease and economic implications, evidence-based guidelines, the Global initiative for chronic Obstructive Lung Disease (GOLD), were launched more than a decade ago with frequent updates. ${ }^{2}$ 
While more than 12 million Americans are known to have COPD, up to 24 million have evidence of impaired lung function and may have the disease but have not been diagnosed. ${ }^{1}$ The primary risk factor for COPD is smoking. Additional risk factors include exposure to second-hand smoke, occupational dusts and chemicals, air pollution, heredity, a history of childhood respiratory infections, and socioeconomic status. ${ }^{1}$ COPD has a major negative impact on quality of life including imposing limitations on the ability to work, normal physical exertion, household chores, social and family activities, and sleeping patterns. ${ }^{1}$ In addition to these problems with daily life, there is obviously much suffering associated with emergency department visits and hospitalizations caused by COPD exacerbations.

The objective of this article is to summarize the economic and clinical burdens of COPD in the USA for the general clinician. Discussion of the burden of this disease refers to the impact of COPD measured by financial cost, morbidity, and mortality. Additionally, the natural history of COPD will be briefly reviewed as well as the cost of this disease and its treatment. Evidence-based diagnosis and management will be discussed including future directions for COPD therapy.

\section{Natural history of COPD}

COPD is usually a progressive disease. Chronic cough and sputum are most common in some patients, but dyspnea associated with effort is the predominate feature in others. Although certain patients have a slowly progressive reduction in pulmonary function, others experience a rapid decline. A small degree of reversible airway obstruction may be detected in some COPD patients, but in most the airway obstruction is close to irreversible. ${ }^{3}$ While there is no cure for COPD, progression of the disease may be slowed by smoking cessation and avoiding exposure to other noxious agents. ${ }^{2,4}$ Furthermore, optimal management is proven to reduce exacerbations and enhance quality of life.

The natural history and time course of the onset of COPD exacerbations is not fully understood. Exacerbations of COPD are defined as an acute event characterized by worsening respiratory symptoms, beyond normal day-to-day variations, which require a change in medication. ${ }^{2}$ In ambulatory patients with stable COPD, predictors for two or more exacerbations annually include older age, chronic mucus hypersecretion, and decreased forced expiratory volume in the first second of expiration $\left(\mathrm{FEV}_{1}\right){ }^{5}$ Aaron et $\mathrm{al}^{6}$ found that COPD exacerbations exhibit two distinct patterns: gradual and sudden onset. Exacerbations with sudden onset are associated with increased respiratory symptoms but reduced exacerbation recovery times. Hospitalization for COPD exacerbations increases the risk of subsequent mortality regardless of baseline pulmonary function. ${ }^{7}$ Patients with comorbidities such as diabetes and coronary artery disease are more likely to be hospitalized for exacerbations of COPD. ${ }^{6}$ COPD is rarely seen in isolation but rather is often managed with comorbidities including heart failure, lung cancer, diabetes, hypertension, and dyslipidemia. ${ }^{8}$ Systemic inflammation likely plays a key role in the development of these concomitant disease states, and elevated biomarkers such as C-reactive protein are associated with an increased risk of comorbidities. ${ }^{9}$

End-stage COPD is characterized by progressively worsening dyspnea during activities of daily living, and finally even at rest. ${ }^{3}$ Additional symptoms, including cough, difficulty in expectoration, loss of energy, weakness, weight loss, and insomnia, are frequently seen. Understandably, these patients also suffer from anxiety, panic, and depression. Hospital admissions become more common, and patients spend the remaining months of their lives at home, or with hospice care, slowly losing their independence. ${ }^{3}$ Among end-stage COPD patients, factors such as current smoking, comorbidities, low body mass index, and hypoxemia are predictors of survival. ${ }^{3,10}$

\section{Cost of COPD treatment in the USA}

Given the prevalence of COPD in the USA, it is imperative to understand the economic impact a disease of this significance can have. As can be imagined, this debilitating and chronic disease carries a significant and substantial economic burden on individuals and society. Unfortunately, this burden is only going to worsen. According to Murray and Lopez, the 30-year projections for COPD are staggering. Presently, COPD is already the third most common cause of death in the USA, and is expected to match this mark worldwide by the year $2020 .^{11}$ Morbidity data follows this same trend. Multiple factors are responsible for this continued growth including continued tobacco use and dependence combined with the overall increase in life expectancy (allowing individuals to have a greater likelihood of exposure to COPD risk factors). ${ }^{2,12}$

As with all chronic diseases, the associated economic burden is felt in the form of both direct and indirect costs. In 2010, the cost of COPD in the USA was projected to be approximately $\$ 49.9$ billion, which includes $\$ 20$ billion in indirect costs and $\$ 30$ billion in direct health care expenditures. ${ }^{1}$ With a currently estimated prevalence of COPD reaching 12 million in the USA, a mean cost of 
over $\$ 4000$ per patient per year could be projected. These costs can be expected to continue to rise as more patients with evidence of lung function impairment are diagnosed through recent advances in COPD screening initiatives.

Indirect costs refer to the morbidity and mortality caused by the disease. These figures stem from the disabling effects of COPD, which are most commonly exhibited as days off from work. ${ }^{12}$ Physical exertion and sleeping patterns are effectively reduced in $70 \%$ and $50 \%$ of COPD patients, respectively. In addition, half of all COPD patients (51\%) state that their disease hinders their ability to work. ${ }^{1}$ Thornton Snider et $\mathrm{l}^{13}$ conducted an economic evaluation of the association between the diagnosis of COPD in Americans more than 50 years old with employment status and the collection of disability benefits. These researchers found that when patients have COPD, there is a 9 percentage point reduction in the likelihood of being employed, along with a 4 percentage point increase in the probability of collecting Social Security Disability Insurance. These figures rival similar data for patients who have experienced a stroke and exceed all other estimates for major chronic health conditions in the USA including cancer, diabetes, heart disease, and hypertension. ${ }^{13}$ While the comparative indirect economic burden of COPD is noticeably substantial, indirect costs represent only the minority of total dollars spent on the care of COPD patients in the USA.

Direct health care costs, accounting for nearly two-thirds of total COPD dollars, are those related to the detection, treatment, prevention, and rehabilitation of a disease, which include: physician office visits, hospitalizations, home care, and medications. ${ }^{12}$ As would be expected, there is a direct relationship between the severity of COPD and the overall cost of care at the patient level., ${ }^{2}$ Data indicate that with each progressive stage of COPD, as defined in a previous GOLD guideline, patients with stage I COPD experienced the lowest direct cost of $\$ 1681$ per patient per year, stage II patients $\$ 5037$ per patient per year, and those in stage III had the highest cost of $\$ 10,812$ per patient per year. ${ }^{14}$ Hospitalization was identified as the most important cost variable across all three stages of COPD. The hospital stay accounts for roughly $45 \%-50 \%$ of the total direct cost generated by COPD patients. ${ }^{14,15}$ Table 1 describes the median (due to non-normally distributed data) annual costs of COPD treatment.

There is undoubtedly a strong association between COPD exacerbations and hospitalization. In a small study evaluating 127 patients, 77\% of COPD patients experienced an exacerbation during one year. ${ }^{16}$ The mean cost for a COPD exacerbation with hospital admission was estimated to be
Table I Annual median costs for COPD treatment based on disease severity

\begin{tabular}{llll}
\hline Cost categories & \multicolumn{3}{l}{ Severity of COPD } \\
\cline { 2 - 4 } & Stage I* & Stage II* & Stage III* \\
\hline Total medication cost (\%) & $\$ 5 I 2(3 \mathrm{I})$ & $\$ 720(\mathrm{I} 4)$ & $\$ 766(7)$ \\
Total non-medication & $\$ 489(29)$ & $\$ 1659(33)$ & $\$ 3276(30)$ \\
costs $(\%)$ & & & \\
Hospitalization cost $(\%)$ & $\$ 680(40)$ & $\$ 2658(53)$ & $\$ 6770(63)$ \\
Total cost & $\$ 168 \mathrm{I}$ & $\$ 5037$ & $\$ 10,812$ \\
\hline
\end{tabular}

Notes: $* P<0.01$ for each cost variable and total cost across the three severities of COPD. All figures are in US\$ per patient.

Abbreviation: COPD, chronic obstructive pulmonary disease.

$\$ 7100 \cdot \cdot^{17,18}$ In 2006, an estimated 672,000 hospital discharges for COPD were reported. ${ }^{1}$ Thus the direct economic impact from exacerbations of COPD is alarming and remains on the rise.

Although the length of stay for a COPD-related hospitalization has decreased over the past 10 years, the number of admissions to the hospital has remained the same since $1999 .{ }^{19}$ With the findings of the Medicare Payment Advisory Commission and the implementation of the Patient Protection and Affordable Care Act 2010, seven conditions or procedures, including COPD, have gained significant attention given their high rates of hospital admission and readmission. ${ }^{20}$ An evaluation of fee-for-service Medicare beneficiaries who were admitted to the hospital for COPD in 2003-2004 found that $22.6 \%$ of these patients were readmitted within 30 days of their index hospitalization. ${ }^{21}$ More recently, the US Department of Health and Human Services Agency for Healthcare Research and Quality published a statistical brief evaluating over 190,000 index hospitalizations across 15 states. $^{18}$ Of these hospitalizations, $7.1 \%$ had a 30 -day readmission for a principal diagnosis of COPD; however, allcause 30 -day readmissions affected $20.5 \%$ of these patients. An increase in cost with each readmission, ranging from $\$ 8400$ to $\$ 11,100$ based on principal diagnosis and all-cause COPD readmissions, respectively, was also demonstrated. It was noted that certain populations of patients were more likely to be readmitted - African Americans and patients in low income areas were readmitted at rates higher than the average. ${ }^{18}$ Although COPD is not currently included in the active Affordable Care Act core measures, the policy expands in 2015 to include COPD. ${ }^{20}$

Unfortunately, with increasing age and disease severity, exacerbations only become more frequent and severe. ${ }^{20}$ These reports emphasize the need to further optimize COPD diagnosis and management. Reducing exacerbations will not only improve quality of life and slow the progression of disease, but also has the potential to significantly reduce direct health care expenditures. 
Your name:
Today's date:

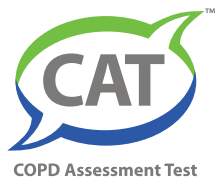

\section{How is your COPD? Take the COPD assessment test ${ }^{\mathrm{TM}}$ (CAT)}

This questionnaire will help you and your healthcare professional measure the impact COPD (Chronic Obstructive Pulmonary Disease) is having on your well being and daily life. Your answers, and test score, can be used by you and your healthcare professional to help improve the management of your COPD and get the greatest benefit from treatment.

For each item below, place a mark $(X)$ in the box that best describes you currently. Be sure to only select one response for each question.

Example: I am very happy 014 I am very sad

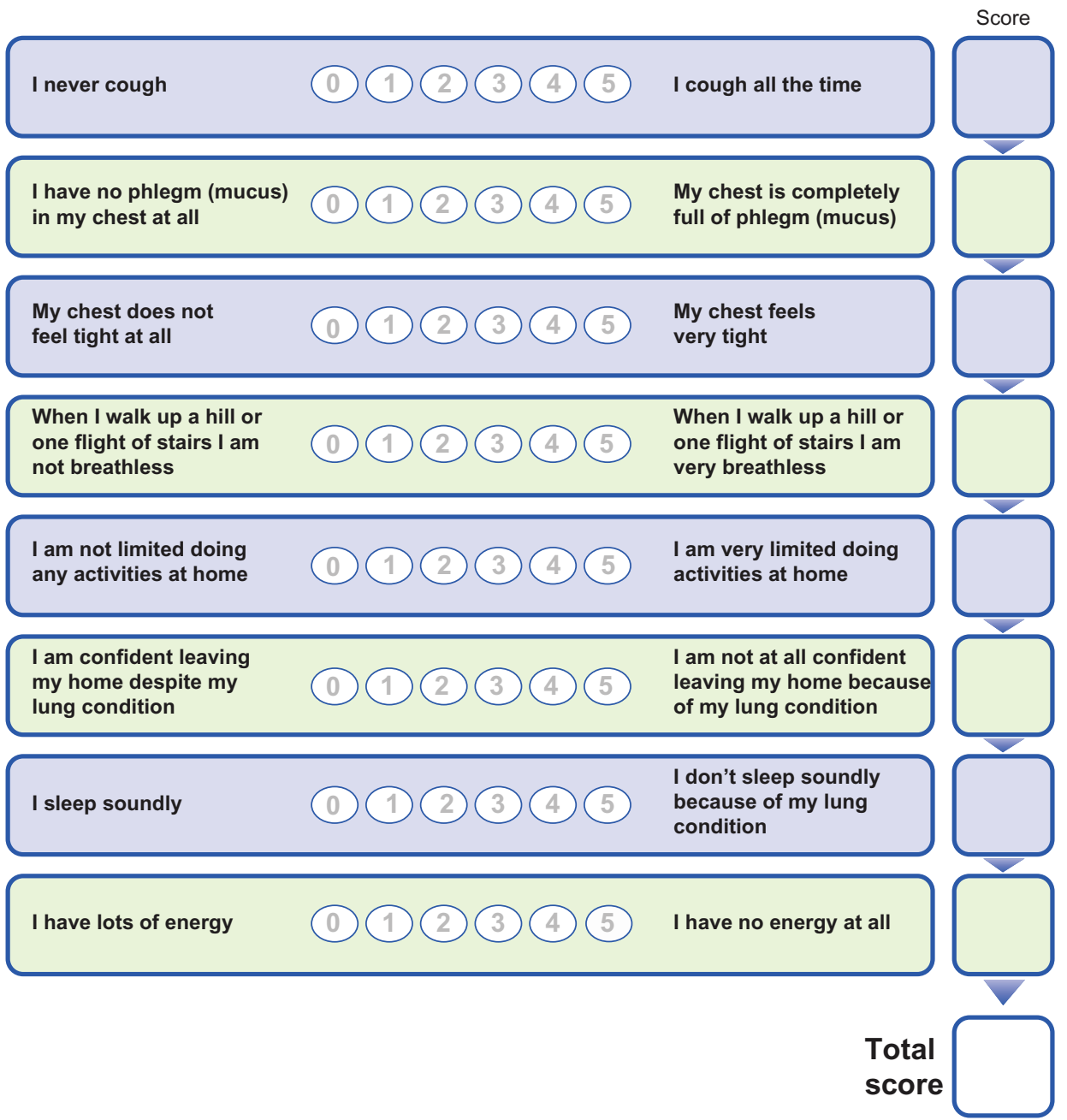

Figure I Evaluative questions from the COPD Assessment Test (CAT).

COPD Assessment Test and the CAT logo is a trade mark of the GlaxoSmithKline group of companies.

(C) 2009 GlaxoSmithKline group of companies. All rights reserved.

Last Updated: February 24, 2012.

Abbreviation: COPD, chronic obstructive pulmonary disease.

\section{Improving COPD diagnosis and management}

Currently, patients are diagnosed with COPD following a multifactorial assessment that includes clinical presentation, symptomatology, and risk factors in combination with the gold-standard of spirometry. Hallmark symptoms of COPD include sputum production, cough, and progressive dyspnea. All patients with suspected COPD should undergo spirometry, which is a necessary component for diagnosis. A pertinent and thorough medical history and physical examination are 
both essential elements for clinical assessment in a patient with suspected COPD. In addition, differential diagnosis should be assessed to ensure that an appropriate diagnosis is made. ${ }^{2,23}$

Misdiagnosis and under-diagnosis continues to be a focal problem in the management of COPD. ${ }^{24}$ While clinicians agree that spirometry is essential for COPD diagnosis, assessments are often omitted in the primary care setting due to various limiting factors. ${ }^{25}$ Barriers to appropriate spirometry evaluation include lack of time for assessment, lack of available resources, and inadequate training of personnel for accurate measurement. Sufficient training for primary care clinicians ${ }^{26}$ and enhanced population screening initiatives for high-risk patients ${ }^{24,27}$ may increase frequency, accuracy, and confidence in spirometry screening practices.

Despite streamlined, appropriate implementation of spirometry, differential diagnosis in COPD is challenging. In particular, differentiation between asthma and COPD can be difficult for clinicians due to substantial overlap in disease presentation and symptoms. A recent study indicates that a spirometry diagnosis of COPD could be made in approximately $17 \%$ of patients previously diagnosed with asthma alone. ${ }^{28}$ Furthermore, patients with COPD can exhibit some respiratory function reversibility, mimicking patients with an asthma diagnosis. Indeed the possibility of both disorders coexisting is likely more common than expected and can influence management strategies. ${ }^{27}$ Clinicians should place importance on a thorough medical history and utilize guidance from international guideline resources to ensure proper classification of these patients. ${ }^{2}$

Due to the aforementioned challenges of diagnosis, various analyses report diagnosis primarily in later stages of the disease. Patients who fall into these later stages of COPD before diagnosis classically exhibit less response to treatment modalities. In addition, while pulmonary function decline is slower in earlier stages of COPD, it becomes more rapid in more advanced disease. ${ }^{30}$ In short, advances resulting in earlier diagnosis can significantly influence the clinical course of COPD management and the natural history of disease progression.

As well as enhancing the frequency and efficiency of spirometry screening, population screening tools have emerged as options to facilitate earlier diagnosis of COPD. These tools attempt to simplify identification of COPD in the general population by providing a straightforward means for individuals to discuss their respiratory symptoms with a clinician. The self-scored COPD population screener questionnaire (COPD-PS) is one such tool that attempts to encompass a broad group of individuals for screening regardless of smoking history, previous diagnosis, or other clinical information. ${ }^{31} \mathrm{~A}$ score from questionnaires such as the COPD-PS is used by clinicians to determine whether or not supplementary assessment of potential COPD diagnosis is necessary. Because the positive predictive value of the COPD-PS is not sufficient for accurate diagnosis alone (approximately $57 \%$ ), it is important to note that this tool is meant specifically for identification purposes rather than to be used as an exclusive diagnostic test. ${ }^{31}$ Although further validation and fine tuning of population screening questionnaires such as the COPD-PS are necessary, these tools will likely play a more substantial role in the early identification of COPD in the future.

A key future component of effective COPD disease management includes an appropriate assessment of disease severity through symptom evaluation to guide therapy. Although spirometry is essential for diagnosis, its role seems to be less well defined in regard to ongoing disease state management. While some sources still promote spirometry use in bronchodilator reversibility testing, this test is no longer recommended due to lack of efficacy as a tool to predict treatment response. ${ }^{2}$ Various assessment tools have been established to better assess COPD disease progress and severity.

The Modified British Medical Research Council (mMRC) questionnaire $^{32}$ and the COPD Assessment Test (CAT) provide a standardized means of COPD-related health status assessment (Figure 1). These tools present a format for assessing the impact of COPD on quality of life indicators to help guide clinicians to properly select appropriate, guideline-recommended treatment strategies. ${ }^{2}$ While the mMRC only evaluates the impact of shortness of breath, the CAT includes assessments of COPD impact on activities of daily living. A recent randomized controlled study indicates that the CAT is a disease-specific instrument that significantly improves the assessment of COPD severity of illness. ${ }^{33}$ These assessment tests are now recommended as a standard means of assessment during patient follow-up visits ${ }^{2}$ and are used in combination with spirometry and assessment of exacerbation risk to guide therapy.

Pulmonary imaging has become an area of interest that may play a more significant role in COPD assessment and care in the future. Quantitative pulmonary imaging can provide greater insight into lung structure and function in comparison with spirometry which can only assess disease severity. ${ }^{31}$ Computed tomography (CT) can provide detailed images of lung structure while magnetic resonance imaging (MRI) can help assess lung function including lung 
parenchyma function and airway thickening. Significant weaknesses of these imaging studies include the need for both CT and MRI studies for appropriate lung assessment, availability, and cost. ${ }^{34}$ Although CT is fast and provides highresolution images, regular CT scans can promote harmful cumulative radiation. ${ }^{35}$ While these imaging modalities can help clinicians assess patients further, they carry with them both disadvantages and risks while their true role in COPD care remains to be established.

Smoking is the single most influential factor in the natural history of COPD. It must be the first step in modifying the clinical course of COPD and reducing the rate of decline in lung function. ${ }^{36-38}$ For this reason, a focus on smoking cessation interventions is likely the principal and most influential factor in COPD management. Although the most important strategy, smoking cessation may prove especially challenging in these patients, and should be approached utilizing both behavioral and pharmacological therapy when appropriate. ${ }^{39}$ Various first line pharmacotherapy options for tobacco dependence, are available, including varenicline, bupropion SR, and nicotine replacement therapies; ${ }^{2}$ treatment selection should be patient-specific, focusing on particular patient characteristics, preference, and contraindications..$^{40,41}$ A comprehensive and multilevel approach to smoking cessation including both patient counseling and support along with pharmacotherapy is optimal, ${ }^{41}$ and this approach has been shown to provide the best benefit for long term quit rates. ${ }^{36}$

Although controversial due to low quality evidence, longterm oxygen therapy has been shown to decrease mortality in patients with severe resting hypoxemia. ${ }^{2,23}$ Likewise, it is currently a common non-pharmacologic therapy recommendation in this patient population in the hope of also improving functional performance and health-related quality of life. ${ }^{2,23}$ However, the same benefit has not been found in patients with mild to moderate hypoxemia. Despite the need for additional studies to illustrate the benefits of long-term oxygen therapy, ethical constraints of withholding oxygen therapy will likely be a limiting factor in future prospective studies. $^{42}$

The anti-inflammatory and immunomodulatory effects of macrolide antibiotics as described in the literature, ${ }^{43}$ along with increased rates of early clinical response with their use, have increased their use in patients with acute infectious COPD exacerbations. ${ }^{44}$ These desirable effects have led to the investigation of macrolides for a potential role in the prevention of acute COPD exacerbations. Modest improvements in time to acute exacerbations, frequency of exacerbations, quality of life, ${ }^{45}$ and also number of moderate to severe exacerbations ${ }^{46}$ have all been reported with the use of macrolide prophylaxis in patients with COPD. As described previously, any reduction in acute exacerbations has the potential to translate into significant economic savings.

However, it is important to note that none of these studies have indicated a mortality benefit, and significant adverse effects and collateral damage from year-long use of macrolide therapy should be seriously considered. Recently, the US Food and Drug Administration issued a Drug Safety Communication on the widespread use of azithromycin, and the risk of potentially fatal heart arrhythmias. ${ }^{47}$ Ototoxicity and the potential for drug-drug interactions should also be considered with long-term macrolide therapy. Perhaps of even greater concern, the spread of antibiotic resistant isolates poses a threat to both macrolides and various other antimicrobials that exhibit similar mechanisms of action, and are thus affected by similar resistance gene mutations. ${ }^{45}$ For these reasons, antibiotic prophylaxis is not endorsed by current guidelines. ${ }^{2}$

\section{Current and emerging options for treatment}

The primary goal of chronic COPD management is stabilization of chronic disease and prevention of exacerbations. Exacerbations not only incur significant morbidity and mortality, but also negatively impact the natural history of the disease causing a progression in disease severity. ${ }^{29}$ While current available pharmacologic therapy for COPD does not prevent progression of the disease, it does offer symptom relief and prevention of exacerbations. Treatment guidelines on selection and escalation of therapy are available. Some direction is given on the appropriate order of agent initiation, but much is left to clinical judgment. ${ }^{2,23}$

Bronchodilators are the mainstay of COPD management. ${ }^{2,23}$ Initial treatment for patients with few symptoms and low exacerbation risk consists of a short-acting bronchodilator, either short-acting beta ${ }_{2}$-agonist (SABA) or short-acting muscarinic antagonist (SAMA) used as needed for breathlessness. Other options include a combination of SABA and SAMA or a long-acting bronchodilator; however, data for the combination of short-acting agents are limite ${ }^{49,50}$ and evidence for long-acting agents is focused on patients with more severe disease..$^{51,52}$

Progression of symptoms, and possible decline in $\mathrm{FEV}_{1}$, warrant the use of long-acting bronchodilators over shortacting agents. Selecting either a long-acting beta $_{2}$-agonist 
(LABA) or long-acting muscarinic antagonist (LAMA) should be based on patient response, preference, and affordability as limited data exist defining the best initial treatment. Some evidence suggests benefit of selecting tiotropium as the initial agent over a LABA, ${ }^{53-56}$ but data are limited. A recent review found equivocal evidence when comparing tiotropium to LABAs for COPD outcomes including quality of life, exacerbations, and mortality. ${ }^{57}$ Consideration must also be given to dosing schedule and inhalation device when selecting therapy. Indacaterol is currently the only LABA available that is dosed once daily, compared with formoterol and salmeterol which are dosed twice daily. Patients with severe symptoms that persist despite treatment with a single long-acting bronchodilator can be considered for combination bronchodilator therapy. Studies evaluating the combination of tiotropium and LABAs have shown improvement in lung function and dyspnea compared with either agent alone.$^{58-60}$ At present, no means are available to deliver these agents together in one device.

Table 2 Cost of common COPD medications

\begin{tabular}{|c|c|c|}
\hline Medication & Usual dose & $\begin{array}{l}\text { Average } \\
\text { monthly } \\
\text { cost in US\$ }\end{array}$ \\
\hline $\begin{array}{l}\text { ProAir }^{\circledR} \text { HFA MDI } \\
\text { (albuterol sulfate) }\end{array}$ & $\begin{array}{l}2 \text { inhalations }(90 \mathrm{mcg}) \\
\text { every } 4 \text { to } 6 \text { hours as } \\
\text { needed }\end{array}$ & $\$ 42$ \\
\hline $\begin{array}{l}\text { Atrovent }{ }^{\circledR} \text { HFA MDI } \\
\text { (ipratropium bromide) }\end{array}$ & $\begin{array}{l}\text { I inhalation }(17 \mathrm{mcg}) \\
\text { every } 6 \text { hours }\end{array}$ & $\$ 150$ \\
\hline $\begin{array}{l}\text { Combivent }^{\circledR} \text { Respimat }^{\circledR} \\
\text { (albuterol/ipratropium) }\end{array}$ & $\begin{array}{l}\text { I inhalation }(20 \mathrm{mcg} / \\
100 \mathrm{mcg}) \text { four times } \\
\text { daily }\end{array}$ & $\$ 275$ \\
\hline Combivent $^{\circledR}$ MDI & $\begin{array}{l}2 \text { inhalations ( } 36 \mathrm{mcg} / \\
90 \mathrm{mcg} \text { ) four times daily }\end{array}$ & $\$ 250$ \\
\hline $\begin{array}{l}\text { Xopenex HFA }{ }^{\otimes} \text { MDI } \\
\text { (levalbuterol tartrate) }\end{array}$ & $\begin{array}{l}\text { I inhalation ( } 45 \mathrm{mcg} \text { ) } \\
\text { every } 4 \text { to } 6 \text { hours as } \\
\text { needed }\end{array}$ & $\$ 54$ \\
\hline $\begin{array}{l}\text { Spiriva }^{\circledR} \text { Handihaler }^{\circledR} \\
\text { (tiotropium bromide) }\end{array}$ & $18 \mathrm{mcg}$ once daily & $\$ 220$ \\
\hline $\begin{array}{l}\text { Tudorza }^{\mathrm{TM}} \text { Pressair } \\
\text { (aclidinium bromide) }\end{array}$ & 400 mcg twice daily & $\$ 265$ \\
\hline $\begin{array}{l}\text { Arcapta }{ }^{\mathrm{TM}} \text { Neohaler }{ }^{\mathrm{TM}} \\
\text { (indacaterol) }\end{array}$ & 75 mcg once daily & $\$ 192$ \\
\hline $\begin{array}{l}\text { Serevent }^{\circledR} \text { Diskus }^{\circledast} \\
\text { (salmeterol xinafoate) }\end{array}$ & $50 \mathrm{mcg}$ twice daily & $\$ 166$ \\
\hline $\begin{array}{l}\text { Foradil }^{\circledR} \text { Aerolizer } \\
\text { (formoterol fumarate) }\end{array}$ & 12 mcg twice daily & $\$ 160$ \\
\hline $\begin{array}{l}\text { Advair Diskus }{ }^{\circledR} \text { (fluticasone } \\
\text { propionate/salmeterol) }\end{array}$ & $\begin{array}{l}250 / 50 \text { mcg twice } \\
\text { daily }\end{array}$ & $\$ 225$ \\
\hline $\begin{array}{l}\text { Symbicort }{ }^{\circledast} \text { (budesonide/ } \\
\text { formoterol fumarate) }\end{array}$ & $\begin{array}{l}160 / 4.5 \text { mcg twice } \\
\text { daily }\end{array}$ & $\$ 215$ \\
\hline Daliresp ${ }^{\circledR}$ (roflumilast) & 500 mcg daily & $\$ 210$ \\
\hline
\end{tabular}

Abbreviations: COPD, chronic obstructive pulmonary disease; HFA, hydrofluoroalkane; mcg, microgram; MDI, metered-dose inhaler.
A number of fixed-dose combinations containing ultraLABAs and LAMAs given once daily are in development for the treatment of COPD.

Indacaterol/glycopyrronium, vilanterol/umeclidinium, and olodaterol/tiotropium bromide are all in clinical trials under investigation for once daily dosing. These agents would offer an option to patients who need combination therapy to control their symptoms, without increasing the burden of additional devices and the need for more than once daily dosing. Unfortunately, diminishing the number of delivery devices does not necessarily correlate to diminishing price, and therefore may not be the ideal option for all patients. Current average monthly costs of common COPD medications can be found in Table 2 . Theophylline may be considered as an option if inhaled bronchodilator therapy is unavailable or unaffordable, but it is less effective and less well tolerated than inhaled bronchodilators. ${ }^{61}$

For patients with frequent exacerbations with or without consistent symptoms, inhaled corticosteroids should be considered. This treatment is in addition to a LABA or LAMA and may even consist of "triple therapy" with all three agents, in patients with more severe disease. Evidence supports the use of the combination LABA/ICS over LABA alone in patients with severe airflow limitation or frequent exacerbations. ${ }^{62-66}$ However, data comparing LABA/ICS to tiotropium are limited ${ }^{67}$ although both have been shown to reduce exacerbations individually. ${ }^{51,62-65,68,69}$ Medications shown to reduce exacerbations in COPD are described in Table 3. Current LABA/ICS combinations, including salmeterol/fluticasone, formoterol/mometasone, and formoterol/budesonide, require twice daily administration. In addition to other twice daily dosed formulations, combinations of ultra-LABAs and ICS such as indacaterol/ mometasone and vilanterol/fluticasone, dosed once-daily are currently being investigated.

Frequent exacerbations of COPD and unrelenting symptoms despite LAMA or LABA/ICS therapy may require consideration for progression to either triple therapy with LAMA and LABA/ICS or addition of a phosphodiesterase-4 inhibitor. Improvement in lung function has been consistently reported with triple therapy compared with LAMA or LABA/ICS alone; ${ }^{70-72}$ however, data on reduction in exacerbations have varied. ${ }^{70,72}$ Roflumilast, a phosphodiesterase- 4 inhibitor, may be added if the patient has symptoms of chronic bronchitis and frequent exacerbations despite bronchodilator therapy. Despite less clear data in patients on ICS, roflumilast has been shown to 
Table 3 Reduction in COPD exacerbations ${ }^{54-57,59-61,65}$

\begin{tabular}{|c|c|c|c|}
\hline Trial/duration & Intervention & Population & Outcomes \\
\hline $\begin{array}{l}\text { Calverley et } \mathrm{al}^{62} \\
12 \text { months }\end{array}$ & $\begin{array}{l}\text { Salmeterol + fluticasone } \\
\text { Salmeterol } \\
\text { Fluticasone } \\
\text { Placebo }\end{array}$ & $\begin{array}{l}\text { Moderate to } \\
\text { severe COPD }\end{array}$ & $\begin{array}{l}\downarrow \text { number of exacerbations for all active treatments compared } \\
\text { to placebo ( } P=0.003 \text { for salmeterol and fluticasone alone, } \\
P<0.000 \text { I for combo) } \\
\downarrow \text { number of exacerbations requiring oral corticosteroids for all } \\
\text { active treatments compared to placebo ( } P<0.000 \text { I for combo } \\
\text { and fluticasone, } P=0.003 \text { for salmeterol and fluticasone alone) }\end{array}$ \\
\hline $\begin{array}{l}\text { Calverley et } \mathrm{al}^{63} \\
12 \text { months }\end{array}$ & $\begin{array}{l}\text { Budesonide }+ \text { formoterol } \\
\text { Budesonide } \\
\text { Formoterol } \\
\text { Placebo }\end{array}$ & $\begin{array}{l}\text { Severe to very } \\
\text { severe COPD }\end{array}$ & $\begin{array}{l}\uparrow \text { time to first exacerbation in budesonide/formoterol compared } \\
\text { to all other groups }(P<0.05) \\
\downarrow \text { total number of exacerbations in budesonide/formoterol compared } \\
\text { to placebo }(P=0.029) \text { and budesonide alone }(P<0.05) \text { but not } \\
\text { budesonide alone }(P=0.308) \\
\downarrow \text { exacerbations requiring oral corticosteroids in budesonide/ } \\
\text { formoterol compared to placebo }(P<0.00 \mathrm{I}) \text { and budesonide and } \\
\text { formoterol alone }(P<0.0 \mathrm{I})\end{array}$ \\
\hline $\begin{array}{l}\text { Szafranski W et al }{ }^{64} \\
12 \text { months }\end{array}$ & $\begin{array}{l}\text { Budesonide }+ \text { formoterol } \\
\text { Budesonide } \\
\text { Formoterol } \\
\text { Placebo }\end{array}$ & $\begin{array}{l}\text { Moderate to } \\
\text { severe COPD }\end{array}$ & $\begin{array}{l}\downarrow \text { in severe exacerbations with budesonide/formoterol compared } \\
\text { to placebo }(P=0.035) \text { and formoterol alone }(P=0.043) \text { but not } \\
\text { budesonide alone }(P=0.385) \\
\downarrow \text { in mild exacerbations in all treatments compared to placebo } \\
(P<0.00 \mathrm{I}) \text { and budesonide/formoterol compared to budesonide } \\
(P=0.022) \text { and formoterol }(P=0.403)\end{array}$ \\
\hline $\begin{array}{l}\text { Calverley et } \mathrm{al}^{65} \\
3 \text { years }\end{array}$ & $\begin{array}{l}\text { Salmeterol + fluticasone } \\
\text { Salmeterol } \\
\text { Fluticasone } \\
\text { Placebo }\end{array}$ & $\begin{array}{l}\text { Moderate to } \\
\text { severe COPD }\end{array}$ & $\begin{array}{l}\downarrow \text { number of exacerbations for all active treatments compared to } \\
\text { placebo }(P<0.00 \mathrm{I}) \text { and for combo compared to salmeterol } \\
(P=0.002) \text { and fluticasone }(P=0.02) \\
\downarrow \text { number of exacerbations requiring systemic corticosteroids for all } \\
\text { active treatments compared to placebo }(P<0.00 \mathrm{I}) \text { and for combo } \\
\text { compared to salmeterol }(P<0.00 \mathrm{I}) \text { and fluticasone }(P=0.02) \\
\downarrow \text { number of exacerbations requiring hospitalization for salmeterol } \\
(P=0.02) \text { and combo }(P=0.03)\end{array}$ \\
\hline $\begin{array}{l}\text { Wedzicha JA et al }{ }^{67} \\
2 \text { years }\end{array}$ & $\begin{array}{l}\text { Salmeterol + fluticasone } \\
\text { Tiotropium }\end{array}$ & $\begin{array}{l}\text { Severe to very } \\
\text { severe COPD }\end{array}$ & $\begin{array}{l}\text { No difference in overall exacerbation rates }(P=0.656) \text { or } \\
\text { exacerbations requiring hospitalization }(P=0.085) \\
\downarrow \text { exacerbations requiring oral corticosteroids with salmeterol/ } \\
\text { fluticasone }(P=0.039) \\
\downarrow \text { exacerbations requiring antibiotics with tiotropium }(P=0.028)\end{array}$ \\
\hline $\begin{array}{l}\text { Niewoehner et al }{ }^{68} \\
6 \text { months }\end{array}$ & $\begin{array}{l}\text { Tiotropium } \\
\text { Placebo }\end{array}$ & $\begin{array}{l}\text { Moderate to } \\
\text { severe COPD }\end{array}$ & $\begin{array}{l}\uparrow \text { time to first exacerbation }(P=0.028) \text { and first hospitalization } \\
(P=0.055) \\
\downarrow \text { frequency of exacerbations }(P=0.031) \text {, exacerbation days } \\
(P=0.019) \text {, antibiotic days for exacerbation }(P=0.015) \text {, unscheduled } \\
\text { visits for exacerbations }(P=0.019) \text {, and hospitalizations for } \\
\text { exacerbations }(P=0.047)\end{array}$ \\
\hline $\begin{array}{l}\text { Tashkin DP et al }{ }^{69} \\
4 \text { years }\end{array}$ & $\begin{array}{l}\text { Tiotropium } \\
\text { Placebo }\end{array}$ & $\begin{array}{l}\text { Moderate to very } \\
\text { severe COPD }\end{array}$ & $\begin{array}{l}\uparrow \text { time to first exacerbation }(P<0.00 \mathrm{I}) \\
\downarrow \text { number of exacerbations }(P<0.00 \mathrm{I})\end{array}$ \\
\hline Calverley et $\mathrm{al}^{74}$ & Roflumilast & Severe to very & $\downarrow$ number of moderate or severe exacerbations $(P=0.003)$ \\
\hline 52 weeks & Placebo & severe COPD & $\uparrow$ time to first $(P=0.0185)$ and second exacerbation $(P=0.0014)$ \\
\hline
\end{tabular}

Abbreviation: COPD, chronic obstructive pulmonary disease.

be effective in reducing exacerbations in patients treated with long-acting bronchodilators. ${ }^{73,74}$

In addition to a variety of novel ultra-LABAs, LAMAs and combination bronchodilator and ICS therapies, other bronchodilators with a variety of mechanisms are also being considered for expanding therapeutic options for the treatment of COPD. Prostaglandin E receptor 4 (EP4), bitter taste receptors (TAS2Rs) of the tongue, and inhaled dual phosphodiesterase-3/phosphodiesterase-4 inhibitors are being evaluated as drug targets for COPD. ${ }^{75}$ In addition, agents targeting CD8+ T cells, and inhibitors of $\mathrm{NF}_{\mathrm{K}_{\mathrm{K}}} \mathrm{B}$, chemokine-receptors 2 and 3, T-helper-17 cells and MAP kinase p38 are also being investigated for their role in managing chronic COPD. ${ }^{76}$ Finally, the role of vitamin D supplementation on the disease course is also being evaluated in randomized trials. With over 50 new medications in the pipeline for the treatment of COPD, optimal management will continue to evolve and grow more complex with 
balancing benefits of therapy with the limitations and needs of each patient.

In addition to pharmacologic therapies, a few nonpharmacologic therapies may also be considered for the treatment of COPD. Pulmonary rehabilitation is recommended to reduce dyspnea, improve health-related quality of life, and reduce hospital days and other measures of health-care utilization. ${ }^{77}$ Current guidelines recommend a program of at least 6 weeks duration that includes exercise training, smoking cessation, nutrition counseling, and education. ${ }^{2}$ Pulmonary rehabilitation has been recognized as cost-effective in the treatment of COPD, irrespective of its undetermined effect on mortality. ${ }^{77}$ Patients who experience shortness of breath when walking at their own pace on level ground should be offered pulmonary rehabilitation. ${ }^{2}$

Various surgical interventions are available for consideration in the management of medically refractory, advanced stage COPD. Lung volume reduction surgery involves an excision of emphysematous lung tissue to decrease lung volume and reduce hyperinflation. ${ }^{75}$ Bullectomy can be considered for excision when air-filled pockets (bullae) are present in the lung affecting surrounding lung tissue. Lung transplantation is an additional alternative surgical option which can completely replace malfunctioning lung, but typically a waiting period is required, it is a more invasive surgical procedure, and transplantation carries serious risks such as organ rejection and the need for lifelong immunosuppressive therapy. ${ }^{2}$ Careful patient assessment and selection should include a comprehensive risk benefit assessment before consideration of surgical palliation. ${ }^{79}$

\section{Conclusion and future directions}

COPD is a complex, multifactorial, and progressive disease associated with significant morbidity and mortality in the USA. The rising economic burden of COPD correlates with increases in disease severity, and hospital admissions and readmissions account for a significant bulk of cost across all stages of COPD. Early, appropriate behavioral and pharmacotherapy options to reduce COPD exacerbations are essential for slowing disease progression, increasing patient quality of life, and subsequently reducing the overall cost burden of this disease state.

Despite the known clinical and economic devastation this disease causes, a great deal remains unknown about optimal therapy. Specifically, more conclusive evidence is needed concerning ideal therapy selection and appropriate sequencing of therapy. Additionally, the role of screening tools in facilitating early diagnosis of COPD and the impact of early treatment on cost and patient outcomes need further delineation. Fortunately, a renewed interest in identifying new drug targets and novel pharmacotherapy for the management of COPD is being observed. It is imperative that the role these new agents play in the management of this disease is clearly elucidated. The anticipated high cost of these new therapies will ultimately have to be balanced with their overall benefit in disease state management and the specific medical and financial needs of the individual patient.

\section{Disclosure}

Dr Chris Finch is a speaker for GSK (Advair) and consultant for Sunovion Pharmaceuticals (Brovana). No financial support was received for this manuscript. The authors report no conflicts of interest in this work.

\section{References}

1. American Lung Association [updated 2011]. COPD Fact Sheet. Available from: http://www.lung.org/lung-disease/copd/resources/factsfigures/COPD-Fact-Sheet.html. Accessed October 9, 2012.

2. Global Initiative for Chronic Obstructive Lung Disease (GOLD) 2013. Global Strategy for the Diagnosis, Management and Prevention of COPD. Available from: http://www.goldcopd.org. Accessed January 29, 2013.

3. Viegi G, Pistelli F, Sherrill DL, Malo S, Baldacci S, Carrozzi L. Definition, epidemiology and natural history of COPD. Eur Respir J. 2007;30:993-1013.

4. Fletcher C, Peto R. The natural history of chronic airflow obstruction. BMJ. 1977;1:1645-1648.

5. Miravitlles M, Guerrero T, Mayordomo C, Sanchez-Agudo L, Nicolau F, Segu JL. Factors associated with increased risk of exacerbation and hospital admission in a cohort of ambulatory COPD patients: a multiple logistic regression analysis. The EOLO Study Group. Respiration. 2000;67:495-501.

6. Aaron SD, Donaldson GC, Whitmore GA, Hurst JR, Ramsay T, Wedzicha JA. Time course and pattern of COPD exacerbation onset. Thorax. 2012;67:238-243.

7. Garcia-Aymerich J, Pons IS, Mannino DM, Maas AK, Miller DP, Davis KJ. Lung function impairment COPD hospitalisations and subsequent mortality. Thorax. 2011;66:585-590.

8. Fabbri LM, Luppi F, Beghé B, Rabe KF. Complex chronic comorbidities of COPD. Eur Respir J. 2008;31:204-212.

9. Thomsen M, Dahl M, Lange P, Vestbo J, Nordestgaard BG. Inflammatory biomarkers and comorbidities in chronic obstructive pulmonary disease. Am J Respir Crit Care Med. 2012;186:982-988.

10. Marti S, Munoz X, Rios J, Morell F, Ferrer J. Body weight and comorbidity predict mortality in COPD patients treated with oxygen therapy. Eur Respir J. 2006;27:689-696.

11. Murray CJ, Lopez AD. Alternative projections of mortality and disability by cause 1990-2020: Global Burden of Disease Study. Lancet 1997;349:1498-1504.

12. Chapman KR, Mannino DM, Soriano JB, et al. Epidemiology and costs of chronic obstructive pulmonary disease. Eur Respir J. 2006;27: $188-207$.

13. Thornton Snider J, Romley JA, Wong KS, Zhang J, Eber M, Goldman DP. The disability burden of COPD. COPD. 2012;9(5):513-521.

14. Hilleman DE, Dewan N, Malesker M, Friedman M. Pharmacoeconomic evaluation of COPD. Chest. 2000;118:1278-1285.

15. Toy EL, Gallagher KF, Stanley EL, Swensen AR, Duh MS. The economic impact of exacerbations of chronic obstructive pulmonary disease and exacerbation definition: a review. COPD. 2010;7: 214-228. 
16. O'Reilly JF, Williams AE, Holt K, Rice L. Defining COPD exacerbations: impact on estimation of incidence and burden in primary care. Prim Care Respir J. 2006;15:346-353.

17. Connors AF Jr, Dawson NV, Thomas C, et al. Outcomes following acute exacerbation of severe choronic obstructive pulmonary disease. Am J Respir Crit Care Med. 1996;154:959-967.

18. Elixhauser A, Au DH, Podulka J. Statistical Brief\#121: Readmissions for Chronic Obstructive Pulmonary Disease, 2008. US Agency for Healthcare Research and Quality. Available from: http://www.hcup-us. ahrq.gov/reports/statbriefs/sb121.pdf. Accessed December 20, 2012.

19. American Lung Association. Trends in COPD (Chronic Bronchitis and Emphysema): Morbidity and mortality. Available from: http://www. lung.org/finding-cures/our-research/trend-reports/copd-trend-report. pdf. Accessed May 2, 2013.

20. Center for Medicare Advocacy. Medicare Hospital Readmissions. Available from: http://www.medicareadvocacy.org/2012/05/02/ medicare-hospital-readmissions/. Accessed May 2, 2013.

21. Jencks SF, Williams MV, Coleman EA. Rehospitalizations among patients in the Medicare Fee-for-Service program. $N$ Engl J Med. 2009;360:1418-1428.

22. Hurst JR, Vestbo J, Anzueto A, et al. Susceptibility to exacerbation in chronic obstructive pulmonary disease. $N$ Engl J Med. 2010;363: $1128-1138$.

23. Qaseem A, Wilt TJ, Weinberger SE, et al. Diagnosis and management of stable chronic obstructive pulmonary disease: a clinical practice guideline update from the American College of Physicians, American College of Chest Physicians, American Thoracic Society, and European Respiratory Society. Ann Intern Med. 2011;155: 179-191.

24. Soriano JB, Zielinski J, Price D. Screening for and early detection of chronic obstructive pumonary disease. Lancet. 2009;374: 721-732.

25. Joish VN, Brady E, Stockdale W, Brixer DI, Dirani R. Evaluating diagnosis and treatment patterns of COPD in primary care. Treat Respir Med. 2006;5:283-293.

26. Yawn BP, Enright PL, Lemanske RF, et al. Spirometry can be done in family physicians' offices and alters clinical decisions in management of asthma and COPD. Chest. 2007;132(4):1162-1168.

27. Zielinski J, Bednarek M. Early detection of COPD in a highrisk population using spirometric screening. Chest. 2001;119: 731-736.

28. Melbye H, Drivenes E, Dalbak LG, Leinan T, Hoegh-Henrichsen S, Ostrem A. Asthma, chronic obstructive pulmonary disease, or both? Diagnostic labeling and spirometry in primary care patients aged 40 years or more. Int J Chron Obstruct Pulmon Dis. 2011;6: 597-603.

29. Price D, Yawn B, Jones RCM. Improving the differential diagnosis of chronic obstructive pulmonary disease in primary care. Mayo Clin Proc. 2010;85:1122-1129.

30. Tantucci C, Modina D. Lung function decline in COPD. Int $J$ Chron Obstruct Pulmon Dis. 2012;7:95-99.

31. Martinez FJ, Raczek AE, Seifer FD, et al. Development and initial validation of a Self-Scored COPD Population Screener Questionnaire (COPD-PS). COPD. 2008;5:85-95.

32. Bestall JC, Paul EA, Garrod R, Gornham R, Jones PW, Wedzicha JA. Usefulness of the Medical Research Council (MRC) Dyspnea Scale as a measure of disability in patients with Chronic Obstructive Pulmonary Disease. Thorax. 1999;54:581-586.

33. Gruffydd-Jones K, Marsden HC, Holmes S, et al. Utility of COPD Assessment Test (CAT) in primary care consultations: a randomised controlled study. Prim Care Respir J. 2013;22:37-43.

34. Washko GR. The role and potential of imaging in COPD. Med Clin North Am. 2012;96:729-743.

35. Brenner DJ, Hall EJ. Computed tomography - an increasing source of radiation exposure. $N$ Engl J Med. 2007;357:2277-2284.
36. Anthonisen NR, Connett JE, Kiley JP, et al. Effects of smoking intervention and the use of an inhaled anticholinergic bronchodilator on the rate of decline of FEV1. The Lung Health Study. JAMA. 1994;272: 1497-1505.

37. Burchfiel CM, Marcus EB, Curb JD, et al. Effects of smoking and smoking cessation on longitudinal decline in pulmonary function. $\mathrm{Am}$ J Respir Crit Care Med. 1995;151:1778-1785.

38. Tonnesen P, Mikkelsen K, Bremann L. Nurse-conducted smoking cessation in patients with COPD using nicotine sublingual tablets and behavioral support. Chest. 2006;130:334-342.

39. Jimenez-Ruiz CA, Masa F, Miravitlles M, et al. Smoking characteristics: differences in attitudes and dependence between healthy smokers and smokers with COPD. Chest. 2001;119:1365-1370.

40. The Tobacco Use and Dependence Clinical Practice Guideline Panel, Staff, and Consortium Representatives. A Clinical Practice Guideline for Treating Tobacco Use and Dependence: a US Public Health Service Report. JAMA. 2000;283:3244-3254.

41. Fiore MC, Hatsukami DK, Baker TB. Effective tobacco dependence treatment. JAMA. 2002;288:1768-1771.

42. COPD Working Group. Long-term oxygen therapy for patients with chronic obstructive pulmonary disease (COPD): an evidence-based analysis. Ont Health Technol Assess Ser. 2012;12:1-64.

43. Kanoh S, Rubin BK. Mechanisms of action and clinical application of macrolides as immunomodulatory medications. Clin Microbiol Rev. 2010;23:590-615.

44. Milstone AP. Use of azithromycin in the treatment of acute exacerbations of COPD. Int J Chron Obstruct Pulmon Dis. 2008;3:515-520.

45. Albert RK, Connett J, Bailey WC, et al; COPD Research Network. Azithromycin for prevention of exacerbations of COPD. N Engl J Med. 2011;365:689-698.

46. Seemungal TAR, Wilkinson TMA, Hurst JR, Perera WR, Sapsford RJ, Wedzicha JA. Long-term erythromycin therapy is associated with decreased chronic obstructive Pulmonary disease exacerbations. Am J Respir Crit Care Med. 2008;178:1139-1147.

47. US Food and Drug Administration. FDA Drug Safety Communication: Azithromycin (Zithromax or Zmax) and the Risk of Potentially Fatal Heart Rhythms. Available from: http://www.fda.gov/drugs/drugsafety/ ucm341822.htm. Accessed March 12, 2013.

48. Wenzel RP, Fowler AA, Edmond MB. Antibiotic prevention of acute exacerbations of COPD. N Engl J Med. 2012;367:340-347.

49. Combivent inhalation aerosol study group. In chronic obstructive pulmonary disease, a combination of ipratropium and albuterol is more effective than either agent alone. An 85-day multicenter trial. Chest. 1994;105:1411-1419.

50. Friedman M, Serby CW, Menjoge SS, Wilson JD, Hilleman DE, Witek TJ. Pharmacoeconomic evaluation of a combination of ipratropium plus albuterol compared with ipratropium alone and albuterol alone in COPD. Chest. 1999;115:635-641.

51. Barr RG, Bourbeau J, Camargo CA, Ram FS. Inhaled tiotropium for stable chronic obstructive pulmonary disease. Cochrane Database Syst Rev. 2005:CD002876.

52. Appleton S, Poole P, Smith B, Veale A, Lasserson TJ, Chan MM. Long-acting beta2-agonists for poorly reversible chronic obstructive pulmonary disease. Cochrane Database Syst Rev. 2006: CD001104.

53. Donohue JF, van Noord JA, Bateman ED, et al. A 6-month, placebocontrolled study comparing lung function and health status changes in COPD patients treated with tiotropium or salmeterol. Chest. 2002;122:47-55.

54. Brusasco V, Hodder R, Miravitlles M, et al; Health outcomes following treatment for six months with once daily tiotropium compared with twice daily salmeterol in patients with COPD. Thorax. 2003;58: 399-404.

55. Vogelmeier C, Kardos P, Harari S, et al. Formoterol mono- and combination therapy with tiotropium in patients with COPD: a 6-month study. Respir Med. 2008;102:1511-1520. 
56. Vogelmeier C, Hederer B, Glaab T, et al; POET-COPD Investigators. Tiotropium versus salmeterol for the prevention of exacerbations of COPD. N Engl J Med. 2011;364:1093-1103.

57. Chon J, Karner C, Poole P. Tiotropium versus long-acting beta-agonists for stable chronic obstructive pulmonary disease. Cochrane Database Syst Rev. 2012:CD009157.

58. Van Noord JA, Aumann JL, Janssens E, et al. Comparison of tiotropium once daily, formoterol twice daily and both combined once daily in patients with COPD. Eur Respir J. 2005;26:214-222.

59. Van Noord JA, Aumann JL, Janssens E, et al. Combining tiotropium and salmeterol in COPD: effects on airflow obstruction and symptoms. Respirol. 2010;104:995-1004.

60. Tashkin DP, Donohue JF, Mahler D, et al. Effects of arformoterol twice daily, tiotropium once daily and their combination in patients with COPD. Respir Med. 2009;103:516-524.

61. Rossi A, Gottfried SB, Higgs BD, Zocchi L, Grassino A, Milic-Emili J. Respiratory mechanics in mechanically ventilated patient with respiratory failure. J Appl Physiol. 1085;131:747-751.

62. Calverley P, Pauwels R, Vestbo J, et al. Combined salmeterol and fluticasone in the treatment of chronic obstructive pulmonary disease: a randomized controlled trial. Lancet. 2003;361:449-456.

63. Calverley PM, Boonsawat W, Cseke Z, Zhong N, Peterson S, Olsson H. Maintenance therapy with budesonide and formoterol in chronic obstructive pulmonary disease. Eur Respir J. 2003;22 912-919.

64. Szafranski W, Cukier A, Ramirez A, et al. Efficacy and safety of budesonide/formoterol in the management of chronic obstructive pulmonary disease. Eur Respir J. 2003;21:74-81.

65. Calverley PM, Anderson JA, Celli B, et al. Salmeterol and fluticasone propionate and survival in chronic obstructive pulmonary disease. N Engl J Med. 2007;256:775-789.

66. Kardos P, Wencker M, Glaab T, Vogelmeier C. Impact of salmeterol/ fluticasone propionate versus salmeterol on exacerbations in severe chronic obstructive pulmonary disease. Am J Respir Crit Care Med. 2007;175:144-149.

67. Wedzicha JA, Calverley PM, Seemungal TA, Hagan G, Ansari Z, Stockley RA. The prevention of chronic obstructive pulmonary disease exacerbations by salmeterol/fluticasone propionate or tiotropium bromide. Am J Respir Crit Care Med. 2008;177:19-26.

68. Niewoehner DE, Rice K, Cote C, et al. Prevention of exacerbations of chronic obstructive pulmonary disease with tiotropium, a once-daily inhaled anticholinergic bronchodilator: a randomized trial. Ann Intern Med. 2005;143:317-326.
69. Tashkin DP, Celli B, Senn S, et al. A 4-year trial of tiotropium in chronic obstructive pulmonary disease. $N$ Engl J Med. 2008;359: $1543-1554$.

70. Aaron SD, Vandemheen KL, Fergusson D, et al. Tiotropium in combination with placebo, salmeterol, or fluticasone-salmeterol for treatment of chronic obstructive pulmonary disease: a randomized trial. Ann Intern Med. 2007;146:545-555.

71. Singh D, Brooks J, Hagan G, Cahn A, O'Connor BJ. Superiority of "triple" therapy with salmeterol/fluticasone propionate and tiotropium bromide versus individual components in moderate to severe COPD. Thorax. 2008;63:592-598.

72. Welte T, Miravitlles M, Hernandez P, et al. Efficacy and tolerability of budesonide/formoterol added to tiotropium in patients with chronic obstructive pulmonary disease. Am J Respir Crit Care Med. 2009;180: 741-750.

73. Fabbri LM, Calverley PM, Izquierdo-Alonso JL, et al. Roflumilast in moderate-to-severe chronic obstructive pulmonary disease treated with longacting bronchodilators: two randomized clinical trials. Lancet. 2009;374:695-703.

74. Calverley PM, Rabe KF, Goehring UM, Kristiansen S, Fabbri LM, Martinez FJ. Roflumilast in symptomatic chronic obstructive pulmonary disease: two randomized clinical trials. Lancet. 2009;374:685-694.

75. Mak G, Hanania N. New bronchodilators. Curr Opin Pharmacol. 2012;12:238-245.

76. Decramer M, Janssens W, Miravitlles M. Chronic obstructive pulmonary disease. Lancet. 2012;379:1341-1351.

77. Ries AL, Bauldoff GS, Carlin BW, et al. Pulmonary Rehabilitation: Joint ACCP/AACVPR Evidence-Based Clinical Practice Guidelines. Chest. 2007;131:4S-42S.

78. Cooper JD, Trulock EP, Triantafillou AN, et al. Bilateral pneumectomy (volume reduction) for chronic obstructive pulmonary disease. J Thorac Cardiovasc Surg. 1995;109:106-116.

79. Sachithanandan A, Badmanaban B. Contemporary surgical management of advanced end stage emphysema: an evidence based review. Med $J$ Malaysia. 2012;67(3):253-258.

80. COPD Assessment Test (CAT). GlaxoSmithKline, Inc; 2009 [updated October 25, 2012]. Available from: http://www.catestonline.org. Accessed January 21, 2013.
ClinicoEconomics and Outcomes Research

\section{Publish your work in this journal}

ClinicoEconomics \& Outcomes Research is an international, peerreviewed open-access journal focusing on Health Technology Assessment, Pharmacoeconomics and Outcomes Research in the areas of diagnosis, medical devices, and clinical, surgical and pharmacological intervention. The economic impact of health policy and health systems

\section{Dovepress}

organization also constitute important areas of coverage. The manuscript management system is completely online and includes a very quick and fair peer-review system, which is all easy to use. Visit http://www.dovepress.com/testimonials.php to read real quotes from published authors. 